\title{
SCREENING OF HUNGARIAN CATTLE HERDS FOR SEROPOSITIVITY TO MYCOPLASMA BOVIS
}

\author{
László FODOR $^{1 *}$, Katalin JÁNOSI ${ }^{1}$, László MAKRAI ${ }^{1}$ and Miklós GYURANECZ ${ }^{2}$ \\ ${ }^{1}$ University of Veterinary Medicine, Department of Microbiology and Infectious Diseases, \\ Hungária krt. 23-25, H-1143 Budapest, Hungary; ${ }^{2}$ Institute for Veterinary Medical \\ Research, Centre for Agricultural Research, Hungarian Academy of Sciences, Budapest, \\ Hungary
}

(Received 27 December 2016; accepted 4 April 2017)

\begin{abstract}
A total of 860 serum samples collected at 86 cattle farms in different parts of Hungary were screened for the presence of antibodies to Mycoplasma bovis using an ELISA test with a recombinant $M$. bovis membrane protein as antigen. Antibodies to $M$. bovis were detected in sera collected on all farms, and no farms negative for $M$. bovis were found. In $88.38 \%$ of the herds more than $50 \%$ of the sampled animals were infected by $M$. bovis. A total of $82.91 \%$ of the animals had antibodies to $M$. bovis. The proportion of seropositive animals was higher in the older age groups, and a significant difference was seen in the level of seropositivity between young and older age groups. The results show that $M$. bovis infection is widespread on Hungarian dairy farms, and its prevalence has increased in the recent decade. The high infection rate of Hungarian cattle herds with M. bovis shows that special attention should be paid to evaluating the aetiological role of M. bovis in bovine respiratory disease complex (BRDC) cases because M. bovis has an immunosuppressive effect and can predispose cattle to other respiratory infections, too.
\end{abstract}

Key words: Mycoplasma bovis, antibody, ELISA, seropositivity

The bovine respiratory disease complex (BRDC) is one of the most important diseases of cattle causing considerable losses all over the world, and $M y$ coplasma bovis is an important agent in its aetiology (Cusack et al., 2003; Nicholas and Ayling, 2003). It is responsible for a wide range of clinical diseases including bronchopneumonia, arthritis, genital diseases, mastitis (Gagea et al., 2006b; Arcangioli et al., 2008; Bürki et al., 2015), otitis (Arcangioli et al., 2012) and keratoconjunctivitis (Kirby and Nicholas, 1996). By replicating on the mucous membranes of the respiratory tract and interacting with other pathogenic bacteria, it compromises the defence mechanism of the host and has a synergistic effect with the pathogenic activity of other bacteria (Gagea et al., 2006a). It is an

*Corresponding author; E-mail: fodor.laszlo@univet.hu; Phone: 0036 (1) 251-9900; Fax: 0036 (1) 251-9260 
important agent of pneumonia at the beginning of the feeding period and in young dairy calves (Gagea et al., 2006a; Giovannini et al., 2013). According to Nicholas and Ayling (2003), M. bovis is responsible for one quarter to one third of the losses caused by bovine respiratory diseases.

Several methods are used for the detection of M. bovis or the antibodies produced to it. Besides isolation of the agent, capture ELISA and different PCR methods are available (Tenk et al., 2002; Nicholas and Ayling, 2003; Tenk et al., 2006). Antibodies to $M$. bovis can be detected with ELISA tests using whole cell or chemically treated antigens. To prevent cross-reactions with other mycoplasmas, different membrane proteins are frequently used as antigens in ELISA tests (Adamu et al., 2013; Fu et al., 2014). Some new ELISA tests can even differentiate between vaccinated and naturally infected cattle (Han et al., 2015). The serological detection of $M$. bovis infection is regarded more reliable in the diagnostic work, since antibody levels remain high for many months and the presence of antibodies indicates an invasive infection in contrast to nasal colonisation (Nicholas and Ayling, 2003).

Mycoplasma bovis is widespread in the cattle population: it can be found on the mucous membranes of the respiratory and genital tracts as well as in the udder. This agent could be detected in $11.6 \%$ of lung tissue samples from dairy calves younger than one month (Giovannini et al., 2013), and antibodies to $M$. bovis were found in all veal calves and $76 \%$ of adult cattle at slaughter in Italy (Radaelli et al., 2008). Mycoplasma bovis could be found in $34.4 \%$ of nasal samples from three-month-old calves (Siugzdaite et al., 2012), while it was present in $53.3 \%$ of the respiratory samples of calves in 4 veal herds in Pennsylvania (Soehnlen et al., 2012). A high level of seropositivity (60-100\%) to M. bovis was seen in the majority of veal calves in France, too (Arcangioli et al., 2008). On the other hand, M. bovis was detected in only $2 \%$ of the calves in backgrounding and stocker cattle operations in Georgia in the US (Wiggins et al., 2007), and no $M$. bovis positive sera could be found in 135 randomly selected Norwegian dairy herds (Gulliksen et al., 2009). Mycoplasma bovis had first been detected in Hungarian cattle herds several decades ago (Romváry et al., 1977), and its pathologic importance was confirmed later (Stipkovits et al., 2000; Bashiruddin et al., 2001; Tenk et al., 2004). The latter authors could detect antibodies to M. bovis in $11.3 \%$ of the animals tested; however the agent could be cultured from $37.0 \%$ of the animals.

It is presumed that $M$. bovis as an immunosuppressive agent has an important role in the pathogenesis of BRDC in Hungary but we do not know how widespread the infection is at present. A few years ago 34 large cattle herds were screened (Tenk et al., 2004), but the increased trade of recent years could have changed the figures. This perception is supported by the results of a recent phylogenetic examination of Hungarian M. bovis strains, which has confirmed the heterogeneity of the strains by detecting two clades and five subclades in one of 
the clades (Sulyok et al., 2014). The aim of the present work was to obtain information on the current seroprevalence of $M$. bovis in cattle herds in Hungary in order to assess its possible role in BRDC.

\section{Materials and methods}

Blood samples were collected in 86 large cattle herds from different parts of Hungary between February and October 2008. The samples were collected during routine diagnostic examinations, thus an ethical approval was not required for the study. Altogether 82 dairy herds were included in the screening, together with one beef herd and three herds of mixed use. The size of the herds ranged between 216 and 2600 head of cattle. Ten blood samples were randomly collected in each herd from animals preferably older than three months; however, there were 26 samples which had been collected from calves younger than three months. The age of the animals ranged between 37 days and 7 years. The samples were transported to the laboratory in a cooler box within $4 \mathrm{~h}$ after collection, and the sera were separated and stored at $-18{ }^{\circ} \mathrm{C}$ until tested.

The Bio K 162 Bio-X Mycoplasma bovis ELISA Kit (Bio-X Diagnostics, Jemelle, Belgium) sensitised with a recombinant protein from $M$. bovis was used. The tests were carried out according to the manufacturer's instructions. Briefly, $100 \mu \mathrm{l}$ each of the 1:100 diluted sera was put into two wells of the microtitration plate: one well was sensitised with $M$. bovis protein, while the other served as negative control. The plates were incubated at $37^{\circ} \mathrm{C}$ for $1 \mathrm{~h}$. After washing, the conjugate (a peroxidase-labelled anti-bovine IgG1 monoclonal antibody) was added to the wells and incubated at $37^{\circ} \mathrm{C}$ for $1 \mathrm{~h}$. The plates were washed, hydrogen peroxide substrate and tetramethylbenzidine chromogen were added and incubated at room temperature for $10 \mathrm{~min}$, then the reaction was stopped. The intensity of the blue colour was read at $450 \mathrm{~nm}$ using an ELISA reader (Multiskan EX, Labsystems, MTX Lab Systems Inc.). The test was validated using the positive serum provided by the manufacturer; it was regarded valid if the optical density of the positive serum exceeded the value stated by the producer.

The test was evaluated according to the manufacturer's instructions. To define the exact optical density (OD) value of the sample, the signal of the negative control well was subtracted from the measured value of the sample. This OD was compared with that of the positive serum and expressed as the percentage of the latter (sample coefficient, ODC\%). The ODC\% values were scored; below $10.5 \%$ the test was considered negative, and the positive results were scored between + and +++++ . The average ODC $\%$ of the sera of four age groups $(<3,4$ $6,7-9,10-12,>12$ months) were calculated using the Unscrambler 10.3 programme (CAMO Software AS., Oslo, Norway) and evaluated by Student's $t$-test. The statistical unit was the individual animal. 


\section{Results and discussion}

Antibodies to $M$. bovis were detected in all herds, no M. bovis free herds were found. In most herds $(88.38 \%)$ more than $50 \%$ of the animals were seropositive to M. bovis (Table 1).

\section{Table 1}

Seropositivity of cattle herds to Mycoplasma bovis

\begin{tabular}{lcc}
\hline $\begin{array}{l}\text { Number of positive } \\
\text { samples out of } 10 \\
\text { collected in a herd }\end{array}$ & Number of herds & \% of herds \\
\hline 0 & 0 & 0 \\
1 & 0 & 0 \\
2 & 2 & 2.32 \\
3 & 1 & 1.16 \\
4 & 1 & 1.16 \\
5 & 6 & 6.98 \\
6 & 6 & 6.98 \\
7 & 9 & 10.47 \\
8 & 10 & 11.63 \\
9 & 17 & 19.77 \\
10 & 34 & 39.53 \\
\hline
\end{tabular}

Regarding the seropositivity of the individual animals, only $17.09 \%$ of the cattle were seronegative but most of the seropositive animals did not have high levels of antibodies (Table 2). The level of seropositivity tended to increase with age (Table 3).

Table 2

Seropositivity of individual cattle to Mycoplasma bovis

\begin{tabular}{lccc}
\hline \multicolumn{2}{l}{ Antibodies to M. bovis } & Number of animals & \% of animals \\
\hline Negative & & 147 & 17.09 \\
Positive & + & 525 & 61.05 \\
& ++ & 132 & 15.35 \\
& +++ & 42 & 4.88 \\
& ++++ & 14 & 1.63 \\
& +++++ & 0 & 0 \\
& Total & 713 & 82.91 \\
\hline Total & & 860 & 100 \\
\hline
\end{tabular}

Nowadays the aetiological role of $M$. bovis in BRDC is widely accepted, and there are more and more data on its occurrence in cattle herds in different countries. There are several diagnostic methods for evaluating the level of infec- 
tion in herds. Detection of antibodies to M. bovis is frequently used, as this test shows the infection for a longer time even if antibiotic treatment is performed, and it indicates not only carriage of $M$. bovis on mucous membranes but also invasiveness (Nicholas and Ayling, 2003). When using serological tests, it is difficult to rule out false seropositivity caused by related antigens of other mycoplasmas. The ELISA test applied in the present project is widely used; thanks to its recombinant $M$. bovis membrane protein antigen the reaction is considered specific (Gulliksen et al., 2009; Gabinaitiene et al., 2011; Arcangioli et al., 2012; $\mathrm{Fu}$ et al., 2014). Examination of the sera using further ELISA tests or paired samples could refine the results but our aim was only to obtain information on the current seroprevalence of $M$. bovis in order to assess its possible role in BRDC.

Table 3

Seropositivity of the different age groups of cattle to Mycoplasma bovis

\begin{tabular}{|c|c|c|c|c|c|c|}
\hline \multirow{3}{*}{ Age } & \multirow{3}{*}{$\begin{array}{c}\text { Number of } \\
\text { animals }\end{array}$} & \multicolumn{4}{|c|}{ Antibodies to $M$. bovis } & \multirow{3}{*}{$\begin{array}{l}\text { Average } \\
\text { ODC\% }\end{array}$} \\
\hline & & \multicolumn{2}{|c|}{ Positive } & \multicolumn{2}{|c|}{ Negative } & \\
\hline & & Number & $\%$ & Number & $\%$ & \\
\hline$<90$ days & 26 & 15 & 57.69 & 11 & 42.31 & $18.28^{\mathrm{a}}$ \\
\hline 91-180 days & 678 & 552 & 81.42 & 126 & 18.58 & $28.26^{\mathrm{b}}$ \\
\hline $181-270$ days & 113 & 106 & 93.81 & 7 & 6.19 & $34.38^{\mathrm{c}}$ \\
\hline $271-365$ days & 10 & 10 & 100 & 0 & 0 & $37.08^{\mathrm{bcd}}$ \\
\hline$>365$ days & 22 & 20 & 90.91 & 2 & 9.09 & $28.33^{\mathrm{abcc}}$ \\
\hline No data on age & 11 & 10 & 90.91 & 1 & 9.09 & n. d. \\
\hline Total & 860 & 713 & 82.91 & 147 & 17.09 & n. d. \\
\hline
\end{tabular}

Means within the column with different superscripts differ $(\mathrm{P}<0.05)$; n. d.: not done; ODC: optical density coefficient

The high rate of $M$. bovis infection in the cattle herds examined was rather surprising. A similar evaluation detected $11.3 \%$ seropositivity in Hungary when examining 595 animals in 34 cattle herds using a different type of ELISA; however in some herds the rate of the seropositivity reached 57.2\% (Tenk et al., 2004). According to our data the proportion of seropositive herds increased from $64.7 \%$ to $100 \%$. The majority of animals were weakly positive, which can be due to asymptomatic colonisation of the respiratory mucous membranes by M. bovis. The elevated rate of infection may result from the increased trade of cattle in the recent decade as it is seen in several other countries. According to a survey in Italy, $76 \%$ of beef and $100 \%$ of veal calves were seropositive to M. bovis (Radaelli et al., 2008). A high infection rate was found at a Lithuanian cattle breeding station, where $75 \%$ of 110 day-old calves were seropositive (Gabinaitiene et al., 2011). In 8 out of 9 French feedlots 60 to $100 \%$ of the animals had seroconverted (Arcangioli et al., 2008). Mycoplasma bovis was detected more frequently from 
pneumonic calves (Gagea et al., 2006a; Soehnlen et al., 2012). The proportion of seropositive animals increased with age and a significant difference was seen in the level of seropositivity between young and older animals.

The high infection rate of Hungarian cattle herds with $M$. bovis shows that special attention should be paid to evaluating the aetiological role of $M$. bovis in BRDC cases. The pathogenic impact of $M$. bovis is highly underestimated. As a primary pathogen it can cause various diseases in cattle and due to its immunosuppressive nature it can predispose cattle to other respiratory diseases. The identification of $M$. bovis infection is a precondition of the effective treatment, prevention and control of BRDC.

\section{Acknowledgements}

The test was provided by Bayer Hungária Ltd. and M. Gyuranecz was supported by the Momentum Programme (Lendület LP2012-22) of the Hungarian Academy of Sciences. Our thanks are due to Prof. L. Stipkovits, Zs. Szathmáry and Zs. Szeidemann for their valuable advice and to the numerous veterinarians who helped us in collecting blood samples. The technical support of Ms. T. Halasi is highly appreciated.

\section{References}

Adamu, J. Y., Wawegama, N. K., Browning, G. F. and Markham, P. F. (2013): Membrane proteins of Mycoplasma bovis and their role in the pathogenesis. Res. Vet. Sci. 95, 321-325.

Arcangioli, M. A., Duet, A., Meyer, G., Dernburg, A., Bézille, P., Poumarat, F. and La Grand, D. (2008): The role of Mycoplasma bovis in bovine respiratory disease outbreaks in veal calf feedlots. Vet. J. 177, 89-93.

Arcangioli, M. A., Froux, W., Poumarat, F. and Le Grand, D. (2012): Case reports: Mycoplasma bovis otitis in French dairy calves. Rev. Med. Vet. 163, 284-286.

Bashiruddin, J. B., De Santis, P., Varga, E. and Stipkovits, L. (2001): Confirmation of the presence of Mycoplasma bovis in Hungarian cattle with pneumonia resembling pleuropneumonia. Vet. Rec. 148, 743-746.

Bürki, S., Frey, J. and Pilo, P. (2015): Virulence, persistence and dissemination of Mycoplasma bovis. Vet. Microbiol. 179, 15-22.

Cusack, P. M. V., McMeniman, N. and Lean, I. J. (2003): The medicine and epidemiology of bovine respiratory disease in feedlots. Aust. Vet. J. 81, 480-487.

Fu, P., Sun, Z., Zhang, Y., Yu, Z., Zhang, H., Su, D., Jiang, F. and Wu, W. (2014): Development of a direct competitive ELISA for the detection of Mycoplasma bovis infection based on a monoclonal antibody of $\mathrm{P} 48$ protein. BMC Vet. Res. 10, 42.

Gabinaitiene, A., Siugzdaite, J. and Zilinskas, H. (2011): Laboratory diagnosis of Mycoplasma infection in young cattle. Pol. J. Vet. Sci. 14, 87-93.

Gagea, M. I., Bateman, K. G., van Dreumel, T., McEwen, B. J., Carman, S., Archambault, M., Shanahan, R. A. and Caswell, J. L. (2006a): Diseases and pathogens associated with mortality in Ontario beef feedlots. J. Vet. Diagn. Invest. 18, 18-28.

Gagea, M. I., Bateman, K. G., Shanahan, R. A., van Dreumel, T., McEwen, B. J., Carman, S., Archambault, M. and Caswell, J. L. (2006b): Naturally occurring Mycoplasma bovis-associated pneumonia and polyarthritis in feedlot beef calves. J. Vet. Diagn. Invest. 18, 29-40. 
Giovannini, S., Zanoni, M. G., Salogni, C., Cinotti, S. and Alborali, G. L. (2013): Mycoplasma bovis infection in respiratory disease of dairy calves less than one month old. Res. Vet. Sci. 95, 576-579.

Gulliksen, S. M., Jor, E., Lie, K. I., Loken, T., Akerstedt, J. and Osteras, O. (2009): Respiratory infections in Norwegian dairy calves. J. Dairy Sci. 92, 5139-5146.

Han, X., Khan, F. A., Zhu, X., Zhang, R., Mustafa, R., Hu, C., Chen, Y., Chen, H. and Guo, A. (2015): Establishment of an antibody avidity test to differentiate vaccinated cattle from those naturally infected with Mycoplasma bovis. Vet. J. 203, 79-84.

Kirby, F. D. and Nicholas, R. A. J. (1996): Isolation of Mycoplasma bovis from bullock's eyes. Vet. Rec. 138, 552.

Nicholas, R. A. J. and Ayling, R. D. (2003): Mycoplasma bovis: disease, diagnosis, control. Res. Vet. Sci. 74, 105-112.

Radaelli, E., Luini, M., Loria, G. R., Nicholas, R. A. J. and Scanziani, E. (2008): Bacteriological, serological, pathological and immunohistochemical studies of Mycoplasma bovis respiratory infection in veal calves and adult cattle at slaughter. Res. Vet. Sci. 85, 282-290.

Romváry, J., Rózsa, J., Stipkovits, L. and Mészáros, J. (1977): Pneumonia-arthritis syndrome in calves caused by Mycoplasma bovis (M. agalactiae subsp. bovis) [in Hungarian, with English abstract]. Magy. Allatorvosok 32, 801-806.

Siugzdaite, J., Gabinaitiene, A. and Kerziene, S. (2012): Susceptibility of Mycoplasma bovis field isolates to antimicrobial agents. Vet. Med. (Praha) 57, 575-582.

Soehnlen, M. K., Aydin, A., Murthy, K. S., Lengerich, E. J., Hattel, A. L., Houser, B. A., Fenton, G. D., Lysczek, H. R., Burns, C. M., Townsend, A. M., Brooks, J. W., Wolfgang, D. R. and Jayarao, B. M. (2012): Epidemiology of Mycoplasma bovis in Pennsylvania veal calves. J. Dairy Sci. 95, 247-254.

Stipkovits, L., Ripley, P., Varga, J. and Pálfi, V. (2000): Clinical study of the disease of calves associated with Mycoplasma bovis infection. Acta Vet. Hung. 48, 387-395.

Sulyok, K. M., Kreizinger, Z., Fekete, L., Jánosi, S., Schweitzer, N., Turcsányi, I., Makrai, L., Erdélyi, K. and Gyuranecz, M. (2014): Phylogeny of Mycoplasma bovis isolates from Hungary based on multilocus sequence typing and multiple-locus variable-number tandem repeat analysis. BMC Vet. Res. 10, 108.

Tenk, M., Bálint, Á., Stipkovits, L., Bíró, J. and Dencső, L. (2006): Detection of Mycoplasma bovis with an improved PCR assay. Acta Vet. Hung. 54, 427-435.

Tenk, M., Ball, H. and Stipkovits, L. (2002): Rapid diagnosis of Mycoplasma bovis infection in cattle by capture ELISA test and selective differentiating medium [in Hungarian, with English abstract]. Magyar Allatorvosok 124, 333-336.

Tenk, M., Stipkovits, L. and Hufnagel, L. (2004): Examination of the role of Mycoplasma bovis in bovine pneumonia and a mathematical model for its evaluation. Acta Vet. Hung. 52, 445-456.

Wiggins, M. C., Woolums, A. R., Sanches, S., Hurley, D. J., Cole, D. J., Ensley, D. T. and Pence, M. E. (2007): Prevalence of Mycoplasma bovis in backgrounding and stocker cattle operations. J. Am. Vet. Med. Assoc. 230, 1514-1518. 